\title{
Regulating water reuse for agricultural irrigation: risks related to organic micro-contaminants
}

\author{
Manuela Helmecke' ${ }^{1}$ Elke Fries ${ }^{2}$ and Christoph Schulte ${ }^{1^{*}}$ (1)
}

\begin{abstract}
In recent years, more and more countries see irrigation using reclaimed water as an opportunity to secure and enhance agricultural production. Despite the benefits of water reuse, the scientific community raised several concerns and challenges for human health and the environment. This includes chemical risks. Effluents from urban wastewater treatment plants usually contain a wide range of organic chemicals. Such chemicals remaining in the water after the treatment process may cause hazards for human health, contaminate surrounding soil and water resources, and even compromise drinking water sources. Once crops on irrigated sites are exposed to chemicals, the potential transport to and accumulation in the edible parts of fruits and vegetables need to be controlled to rule out their introduction into the food chain. Finally, problems concerning the release of wastewater-borne antibiotics into the environment are starting to gain attention. For these reasons, agricultural irrigation should face more stringent quality requirements in order to minimize chemical risks. Combinations of measures reducing chemicals at the source, technical and natural water treatment processes especially to remove chemicals with persistent, bioaccumulative and toxic (PBT), or persistent, mobile and toxic (PMT) properties, good agricultural practices, and supplementary preventive measures (e.g. knowledge transfer to the stakeholders involved) will be necessary to bring about and ensure safe irrigation in the future. While internationally many regulations and guidelines for water reuse have successfully been implemented, questions remain whether the current knowledge regarding chemical risks is sufficiently considered in the regulatory context. The introduction of a new regulation for water reuse, as attempted in the European Union, poses a good opportunity to better take chemicals risks into account.
\end{abstract}

\section{Background}

In 2000, German Chancellor Angela Merkel noted that "Globalisation means that we all live in one world. Environmental pollution, resource consumption, and population growth will affect us all more and more in the future". From today's perspective, this can be interpreted as one of the preludes to the challenges associated with global change [1]. One important step toward meeting these challenges was the adoption of the Agenda 2030 for Sustainable Development by the UN General Assembly

\footnotetext{
${ }^{*}$ Correspondence: Christoph.schulte@uba.de

1 Umweltbundesamt, Wörlitzer Platz 1, 06844 Dessau-Roßlau, Germany
}

Full list of author information is available at the end of the article in September 2015. The Sustainable Development Goals (SDG) are intended to fundamentally improve the living conditions of all people and guarantee the protection of the planet [2]. Water is regarded as one of today's "crisis resources", especially in regions with increasing water scarcity [3]. Within SDG 6-which is dedicated explicitly to water aspects-Subgoal 6.3 focuses on substantially increasing water recycling and safe reuse globally by 2030. Water reuse also has many links to other SDGs, such as "no poverty", "zero hunger", "climate action", and "life on land". In addition, the 2017 World Water Development Report highlighted the relevance of water reuse [4]. The Water Strategy of the German Federal Ministry for Economic Cooperation and Development [5] described
Springer Open

(c) The Author(s) 2020. This article is licensed under a Creative Commons Attribution 4.0 International License, which permits use, sharing, adaptation, distribution and reproduction in any medium or format, as long as you give appropriate credit to the original author(s) and the source, provide a link to the Creative Commons licence, and indicate if changes were made. The images or other third party material in this article are included in the article's Creative Commons licence, unless indicated otherwise in a credit line to the material. If material is not included in the article's Creative Commons licence and your intended use is not permitted by statutory regulation or exceeds the permitted use, you will need to obtain permission directly from the copyright holder. To view a copy of this licence, visit http://creativeco mmons.org/licenses/by/4.0/. 
increased reuse of treated wastewater as a goal to reduce water scarcity and its harmful impact on humans. In 2012, the European Union identified the unused potential of water reuse as one response to the problems of water scarcity and drought [6]. This had led to a regulatory proposal published in 2018 [7].

Water reuse has been a long-established practice in several water-scarce countries and regions around the world [8]. Experience dates back to park irrigation in California, USA, since 1912 [9], potable water reuse in Windhoek, Namibia, since 1968 [8], and agricultural irrigation in Israel since the 1950s [10]. The practice of potable water reuse has evolved in important ways in the USA [11]. Israel covers more than $50 \%$ of its agricultural water demand with reclaimed water [12]. In Singapore, "NEWater" meets around $40 \%$ of the water demand [13]. In the EU, reuse projects are more numerous in Southern European countries like Cyprus, France, Greece, Malta, Portugal, and Spain. Several reuse projects have been also implemented in central and northern countries like Belgium, Sweden and UK [14]. Innovative water reuse projects around the world have shown that appropriate technologies can be put in place to treat wastewater to nearly any needed quality, including highly sensitive potable and industrial applications [8]. However, highly advanced water treatment comes at a greater cost and has higher energy requirements. Thus, treatment levels are usually established according to the "fit-to-purpose" approach, setting water-quality goals in relation to end users' needs. This approach is reflected in a variety of legislation and guidelines for water reuse like the World Health Organization's (WHO) guidelines for wastewater use in aquaculture and agriculture [15] and for potable reuse [16] as well as the ISO Guidelines 16075 for treated wastewater use for irrigation [17].

While the risks resulting from pathogen exposure, as well as from potential adverse impacts of nutrients, heavy metals, salinity and sodicity have been widely addressed in guidance documents and regulations [9, 15, 17, 18], chemical risks, in particular hazards from organic microcontaminants, appear to be less in the spotlight. The Joint Research Center (JRC) of the European Commission suggested minimum quality requirements for water reuse in a technical report [19]. These requirements served as a basis for the recent EU regulatory proposal for water reuse for agriculture [7]. The report identified current major knowledge gaps for organic micro-contaminants, such as their role in agricultural systems, their pathways, and the effects of long-term exposure, and proposed a risk management approach to address these risks. This had also been recommended by SCHEER [20].

The present discussion paper attempts to emphasize the significance of adequately considering chemical risks especially in terms of organic micro-contaminants when regulating water reuse for agricultural irrigation. After summarizing the opportunities and benefits of water reuse, the text moves on to chemical risks to foster a subsequent discussion on emerging issues from chemicals in water reuse for agricultural irrigation. Finally, an appropriate risk management system for safe water reuse is proposed to minimize hazards from chemical pollution.

\section{Opportunities and benefits of water reuse}

In water-scarce countries and regions, the recycling of wastewater provides one opportunity to substitute limited freshwater resources with reclaimed water for purposes that do not require drinking water quality. Urban wastewater, which is usually continuous throughout the year, can provide a reliable water source while freshwater availability may be characterized by high seasonal variations or extreme events. Since these patterns are becoming more likely with climate change, interest has grown in water reuse opportunities-and not only in arid countries.

Potential water reuse applications include agricultural and landscape irrigation, industrial reuse, groundwater recharge, urban applications for firefighting, and street cleaning, as well as recreational and ecological uses [9, $8]$. With a market share of around $30 \%$, agriculture is the most common application of reclaimed water [4]. On average, agriculture accounts for $70 \%$ of global freshwater withdrawals [21]. Water shortages in agriculture can have far-reaching effects on food security, nutrition, livelihoods, and other socioeconomic aspects, but a reliable water supply can help to alleviate these pressures and uncertainties. With population growth, increasing food demand, and pressure on water resources, increased water productivity in agriculture is also crucial. In Australia, the introduction of water reuse has facilitated an increase in agricultural production, despite the limited availability of freshwater resources [8]. In Tunisia, where wastewater reuse is a well-established practice, reclaimed water for agricultural purposes consists of about $20 \%$ of wastewater effluents, promoted by the state in order to save freshwater for the drinking water supply and to protect receiving waters $[22,23]$.

Irrigation with reclaimed water may also have benefits in terms of providing nutrients to crops, thus potentially reducing the need for synthetic fertilizers in agriculture [18]. However, ensuring a balance between adequate wastewater treatment and adapting nutrient loads in reclaimed water to specific crop requirements and their seasonal variations can be challenging. Otherwise, excessive nutrients may cause plant damage and leach into groundwater or surface waters. While water reuse can complement or supplement measures for water saving 
and efficiency, it should not replace them. The European Commission has reflected on this by outlining a water hierarchy that clarifies that "additional water supply infrastructures should be considered as an option when other options [to improve efficiency and save water] have been exhausted" [89]. With some estimates stating that the current irrigation efficiency in the EU ranges between 20 and $50 \%$ due to evaporation losses and leakages in conveyance systems, this indicates significant potential for further improvement [24]. With an increasing attention to potentials of water reuse, there are also ongoing studies on related risks and challenges (e.g., Nereus COST ACTION on "New \& emerging challenges and opportunities in wastewater reuse").

\section{Risks of water reuse}

\section{Chemical risks}

The source and composition of wastewater, its treatment, storage and distribution, and the type of irrigation technique and agricultural practice, as well as climate, soil and groundwater conditions all significantly contribute to the specific chemical risks resulting from water reuse.
Potential exposure pathways during water reuse for agricultural irrigation need to be considered. The main types of these pathways are summarized in Fig. 1.

We all use everyday products such as pharmaceuticals, personal care products, cleaning agents, plastics, and other lifestyle products during different activities. This results in the release of thousands of organic chemicalsantibiotics, beverage and food additives, preservatives, corrosion inhibitors, textile chemicals, and biocides, just to name a few-into our wastewater. Some of these chemicals have persistent, bioaccumulative, and toxic (PBT) properties and were defined as substances of very high concern according to the European Chemicals Regulation REACH [25]. Others are hazardous for the water cycle due to persistent, mobile, and toxic (PMT) properties [26]. Urban wastewater treatment eliminates many chemicals only to a limited extent, depending on the treatment conditions [27], but also on input loads, mobility, and resistance to degradation. Nonpolar compounds are mainly distributed into sewage sludge during treatment. However, water-soluble polar compounds remain in the aqueous phase. Persistent polar compounds, such

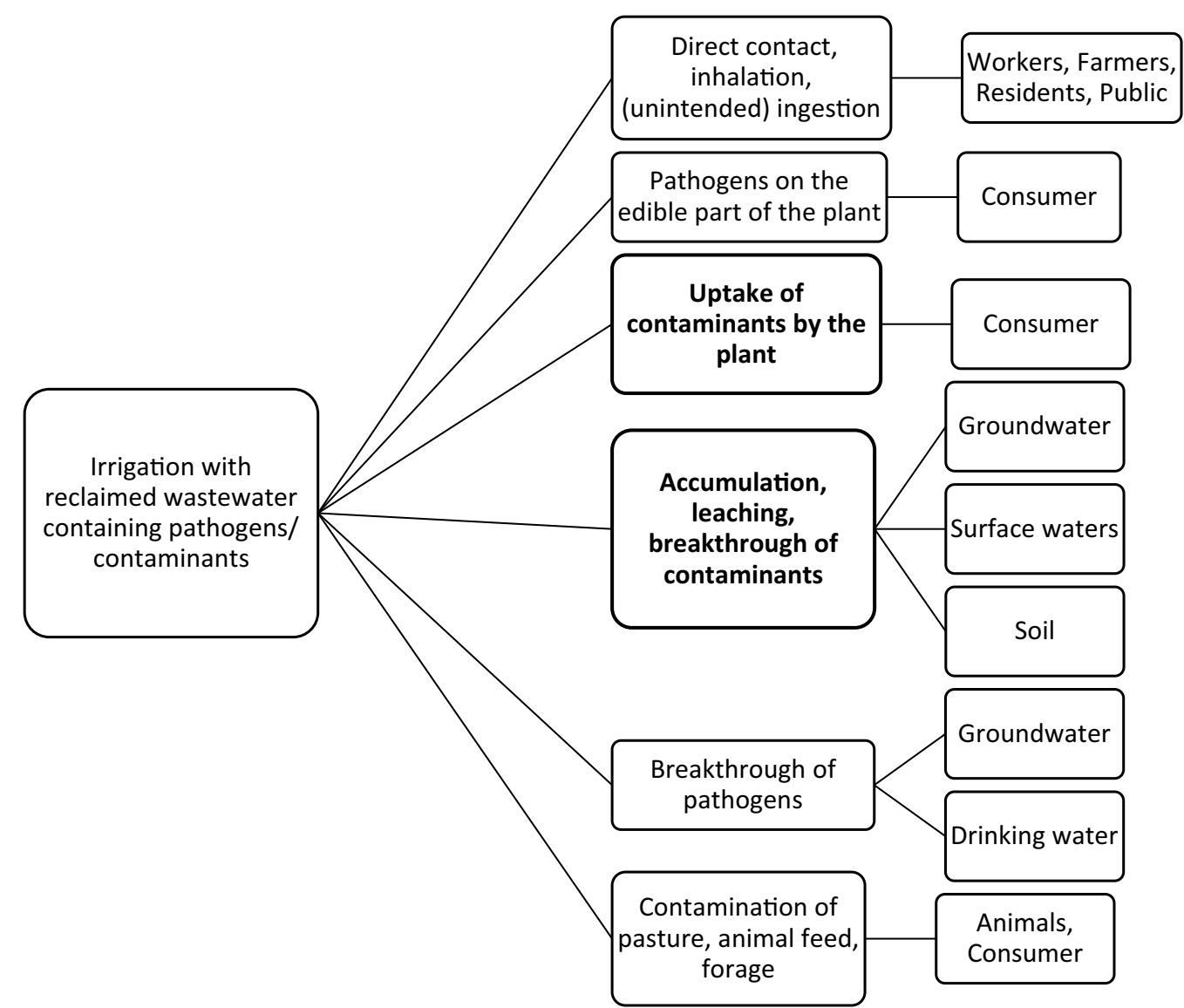

Fig. 1 Simplified overview of potential exposure pathways during water reuse for agricultural irrigation (focus of this article is in bold) 
as per- and polyfluorinated alkyl substances or stable benzotriazoles, as well as polar pseudo-persistent chemicals such as many pharmaceuticals, may end up in wastewater effluents. The latter are principally degradable by biological activity. However, they may pass through conventional wastewater treatment procedures according to a continuous delivery with the influent and/or insufficient retention times in wastewater treatment plants. Consequently, a variety of organic micro-contaminants appear in urban wastewater effluents in Europe [28-33], as well as in middle-income countries such as Tunisia [23, 34-36]. In addition, known and unknown metabolites are produced during wastewater treatment due to the activity of various microorganisms present in sewage sludge $[35,37]$. Findings on these contaminants increase due to the continuous development of analytical tools, thus also referring to them as contaminants of emerging concern (CEC).

By using treated wastewater for irrigating arable land, organic micro-contaminants are introduced into soils and are potentially transferred to the groundwater. For example, Grossberger et al. [38] reported that carbamazepine, lamotrigine, caffeine, metoprolol, sulfamethoxazole, and sildenafil were all persistent in soils. A removal by soil passage is sustainable only for some compounds $[38,39]$ indicating different persistence and mobility in soils. Thus, Williams and McLain [39] found net accumulation in soils for carbamazepine and caffeine, while ibuprofen was completely removed. Fries et al. [35] targeted a broad number of organic compounds in groundwater collected from a wastewater irrigated site in Tunisia for the first time and detected sulfamethoxazole, carbamazepine, methylparaben, propylparaben, $1 \mathrm{H}$-benzotriazole, bisphenol $\mathrm{A}$, and triclosan. In this study, however, the quantities and concentrations of micro-contaminants in groundwater were much lower compared to those in the reclaimed water, indicating that degradation in soil takes place, but is incomplete in the case of some compounds. At two sites in Lower Saxony, exceedances of health-related indication values for X-ray contrast media were detected in groundwater representing an example for the impact of decades of wastewater irrigation [40, 41]. Intrinsic compound parameters play a major role for persistence and mobility of chemicals in soils. This was demonstrated by studies from the world's largest wastewater irrigation system in Mexico City where reservoir storage and soil passage were effective in degrading basic compounds with positive or neutral charges, while acidic, anionic compounds were hardly retained [42].

Potential chemical risks for soil and groundwater resources, and consequently for ecosystem and human health, are always a combination of exposure and effects. In terms of pharmaceuticals and many other organic micro-contaminants, the adverse ecological effects in the environment are still unknown or only suspected, especially in the long term. Some detected compounds can have negative effects on soils' microbial communities and soil functions [18, 43, 45]. More studies are still needed to consider long-term effects in regulations.

Wastewater-borne micro-contaminants can also be taken up by plants [46-51] and may reach the food chain. Accumulation in the edible parts of fruits and vegetables as already described for perfluorinated and polyfluorinated alkyl substances [52-54] has to be considered also for other micro-contaminants. However, there is still a lack of knowledge on the fate and transport for most of organic micro-contaminants in arable soil systems, on root interactions and plant uptake [55]. Prosser and Sibley [56] reported that the majority of individual pharmaceuticals and personal care products in the edible tissue of plants due to biosolids or manure amendment or wastewater irrigation represent a de minimis risk to human health. However, the authors also concluded that assuming additivity, the mixture of pharmaceuticals, and personal care products could potentially present a hazard.

\section{Other risks}

This article focuses primarily on the chemical risks related particularly to organic micro-contaminants, since the contamination of urban wastewater with pathogens is usually considered already as a high-priority risk in water reuse. The latter issue is therefore only briefly addressed here. If pathogens are not fully eliminated in conventional wastewater treatment plants, they can enter natural resources and food chains, with major potential effects on the health of humans and animals (e.g. [18]). While conventional wastewater treatment plants reduce E. coli, other coliform bacteria, and intestinal enterococci by 1 to $4 \log$ units, and viruses by 1 to $2 \log$ units [57], other bacteria, viruses, protozoa, and helminths are still present in treated wastewater $[16,17,58]$. Depending on site-specific conditions, viruses may persist through soil passage and reach groundwater. Compared to bacteria, viruses can remain infectious for much longer periods and may be more mobile in sediment $[59,60]$.

Wastewater treatment plants are also considered hot spots for the dissemination and formation of antibiotic resistance $[57,61,62,63]$ that may be spread by water reuse. Some chemicals may serve as a selective pressure to increase the abundance of resistance genes in soil communities; this has been reported for triclosan and sulfamethoxazole [64]. Findings about the potential uptake of antibiotic-resistant genes and bacteria by crops due to irrigation with reclaimed water are still largely inconclusive $[44,65]$. Relevant studies have been 
conducted as part of recent Nereus COST ACTION on "New \& emerging challenges and opportunities in wastewater reuse."

\section{Adequate risk management for safe water reuse The need for systematic risk assessment}

Potential risks in water reuse for agricultural irrigation differ according to site-specific conditions, the specific composition of wastewater influent, treatment, and irrigation technology, crop selection as well as climate and soil characteristics. To evaluate potential contamination by chemicals, a systematic risk assessment including all relevant exposure pathways is necessary. This needs to be included in a regulation for water reuse or supporting guidelines. The regulation on water reuse in preparation in the EU [7] foresees a risk management approach and outlines key steps. However, the draft remains vague regarding its implementation and lacks guidance how to derive further requirements and measures to prevent chemical risks.

Different risk management approaches have been introduced with, e.g., the Australian Guidelines for Water Recycling [66, 67], the Hazard Analysis and Critical Control Point (HACCP) approach, or the WHO's Water Safety and Sanitation Safety Planning $[68,69]$. The WHO safety planning approach facilitates the analysis of potential hazards in the system, risk assessment, and the creation of measures and monitoring criteria with the involvement of the relevant stakeholders. Portugal, in line with the recent ISO Guidelines [17], proposes a multibarrier approach and a qualitative risk assessment for water reuse to assess the risks for human health and the environment considering the sensitivity/vulnerability of the end-use [70]. This includes the assessment of risk levels of groundwater and surface water in order to define contaminants thresholds [17].

Multiple barriers are needed to effectively mitigate risks along the water reuse system between wastewater generation and its use $[15,17]$. Initially established for public health protection in the water reuse system and the food chain, appropriate multiple barriers can also contribute to reducing the risks of organic microcontaminants. Additionally, when dealing with unknown risks and uncertainty about the contamination of water sources, we propose to follow the precautionary principle to prevent currently unknown long-term impacts [71].

\section{Pollution reduction at the source}

A holistic form of risk management requires also adequate efforts to decrease the entry of micro-contaminants into the environmental system at the source (here: wastewater). This includes for example the raising of awareness about the proper disposal of medical products, support for a general reduction in the use of pharmaceuticals (especially antibiotics) by strengthening health prevention and hygiene, and a reduction in the use of biocides where possible (as well as fostering the development of more sustainable chemicals) $[48,65,90]$. Due to their stability during water treatment, special attention for measures at the source must be paid to PBT and PMT chemicals. Measures at the source resulting in an overall reduction in the contaminant load would also have beneficial effects when the treated wastewater is ultimately discharged into the environment, e.g., for the ecology of the receiving water body, for the marine environment, or for a water body's use for the drinking water supply, swimming, or diversions for irrigation (indirect water reuse).

\section{Wastewater treatment processes}

Due to the presence of wastewater-borne contaminants, advanced water treatment is one crucial element for safe water reuse in particular to remove PBT and PMT chemicals. The treatment level should correspond to the intended use (fit-for-purpose), health and environmental risks considering economic viability, and public acceptance. The efficiency of the treatment processes with regard to chemicals should be validated using chemical analytics and suitable indicators as reported, e.g., by Jekel and Dott [72]. Treatment processes for the removal of organic micro-contaminants differ in their efficiency depending on the wastewater characteristics, the concentrations of the micro-contaminants in the influent, their physicochemical properties, and the treatment conditions [62, 33, 73, 74]. Oxidation with ozone and adsorption using activated carbon has been successfully tested in large-scale applications for the removal of microcontaminants, partly in combination with additional post-treatment steps [57]. However, in case of ozonation, potential transformation products also need to be considered. Reverse osmosis and nanofiltration are promising treatment technologies for highly effective removal of organic micro-contaminants, but challenges remain due to high costs, high energy demand, and disposal of the remaining concentrates and retentates [75, 33, 57]. Ultrafiltration and microfiltration as well as membrane bioreactors have demonstrated incomplete success in the removal of organic micro-contaminants but may be suitable in combination with other processes $[33,57]$. However, ultrafiltration was found to be effective in the removal of antibiotic-resistant genes and bacteria [57]. Advanced oxidation processes have been shown to effectively degrade and deactivate chemical and microbiological contaminants, but there has been limited evidence in full-scale implementation [75, 62]. While few treatment processes may be effective for the removal of selected 
organic micro-contaminants and pathogens, generally no single treatment technology can achieve all purposes (including pathogen removal) by itself. Therefore, a combination of different processes is needed to limit the risks, e.g., combining membrane bioreactors with powdered activated carbon, or ozonation with UV radiation $[9,75,57]$. Nevertheless, due to their specific properties, not all contaminants can be effectively removed. Examples include certain short-chain perfluorinated and polyfluorinated alkyl substances.

Natural processes ('natural attenuation') are well known as low-cost methods to remove chemicals from soil and groundwater in the absence of advanced technical measures [76]. In terms of irrigation, the effectiveness of natural attenuation depends on the load and type of contamination in reclaimed water $[35,38,39]$ and the particular soil conditions [77]. Other factors that must be considered include aquifer and groundwater conditions, climate, irrigation technologies, the irrigation frequency and amount of water. Natural attenuation for the safe reuse of water in agricultural irrigation requires appropriate and continuous evaluation to ensure that there will be no adverse impact on humans or the environment. These evaluations need to include a knowledge-based monitoring concept adapted to individual soil, groundwater and climate conditions. The site-specific chemical and physical properties of the soil, including flow conditions as well as the mass and diversity of microorganisms need to be known and monitored as a basis for modeling contaminant transfer. The dynamics of the natural attenuation potential of the soil system and its resilience have to be studied site-specifically, including attention to possible variation of the soil system in an area and over time. Due to these complexities, natural attenuation might be difficult to instruct in a regulation but could be an alternative or complement to commercial treatment technologies.

\section{Irrigation practices}

Exposure to humans and animals can be reduced by limiting accessibility to fields irrigated with reclaimed water, or by preventing direct contact between the edible part of the plant and the reclaimed water [18]. Irrigation technologies such as drip irrigation and subsurface irrigation not only reduce potential exposure to pathogens and contaminants [65], but also promote water use efficiency and reduce the potential of accumulation and leaching. Access control measures, including safety distances between the irrigated fields and publicly accessible areas, reduce potential contact [17]. Additional measures would include adequate signage of fields irrigated with reclaimed water as well as of pipes transporting reclaimed water [17]. Due to issues concerning the quality of reclaimed water, crops for raw consumption or particularly sensitive areas (e.g., karst) could be excluded from water reuse for irrigation. Piña et al. [65] argued against the use of reclaimed water for the irrigation of leafy vegetables, as these crops were found to show high uptake and bioaccumulation of micro-contaminants and high translocation potential $[48,65]$. In Tunisia for example, the use of reclaimed water in the irrigation of food crops is prohibited, while Cyprus has banned the irrigation of leafy vegetables and bulbs consumed raw with reclaimed water $[19,88]$. Stakeholders should also note when irrigation utilizes groundwater and/or surface water previously affected by wastewater. It should be mentioned that measures aiming to reduce potential exposure to human and animals often do not mitigate wider environmental risks. Therefore, it is also important to consider groundwater sensitivity, soil and climatic conditions as part of the risk management-regardless of crop category and level of accessibility.

\section{Monitoring of organic micro-contaminants}

The findings discussed above regarding the potential translocation and accumulation of organic micro-contaminants highlight the importance of environmental monitoring for the detection of potential adverse effects, including the application of wide-scope approaches for environmental analysis. Recent efforts at EU level aimed to identify chemical and toxicity indicators for the control and reduction in risks related to micro-contaminants for human health and environment (e.g., NORMAN network and EU projects such as PROMOTE, or SOLUTIONS). For this purpose, and to address mixture effects, effect-based methods as suggested by the SOLUTIONS project [78] might be considered as a monitoring tool to ensure safety irrigation in order to implement the EU regulation successfully. Effect-based monitoring may also address risks of unknown micro-contaminants that pose additional constraints for the development of water reuse practices as reported by Lazarova [8]. Since some compounds can also have negative effects on soils' microbial communities and soil functions [18, 43-45], there is a need to adapt effect-based methods to soil matrix and soil ecosystems.

Another promising approach is the monitoring of specific compounds as indicator substances. In principle, higher concentrations of anions and cations could indicate the influence of wastewater on natural resources. One prerequisite for using inorganic compounds, however, is that other sources of ions are absent, e.g., seawater intrusion into groundwater. The literature suggests various organic micro-contaminants as indicators [78-81]. However, to date, there is limited data from long-term soil and groundwater monitoring of organic 
micro-contaminants at water reuse sites. When selecting appropriate indicators for this purpose, compounds' particular persistence and transport behaviors should be taken into account. Since caffeine is frequently detected in treated wastewater, it has been suggested its use as a marker for anthropogenic wastewater contamination [82]. However, despite the high consumption of caffeine, its high degradability in the environment results in very low concentrations [83], and its complete removal during soil passage [35] makes it less suitable for monitoring groundwater effects at sites irrigated with reclaimed water. A study in Lebanon [84] showed that carbamazepine was the only contaminant that showed a breakthrough, while caffeine was only intermittently present. Carbamazepine, sulphamethoxazole, methylparaben, propylparaben, bisphenol A, triclosan, and $1 \mathrm{H}$-benzotriazol have also been suggested as promising indicators due their persistence and their mobility in soils [35]. Young et al. [85] noted that hydrophobic organic wastewater compounds, such as triclosan, might outperform caffeine as a chemical tracer due to their ability to adhere to suspended microorganisms, which can result in a positive correlation with microbial markers.

A legislation for water reuse should come along with a comprehensive framework that assists the establishment of a meaningful monitoring system for organic microcontaminants that allow validating the performance of water treatment processes and monitoring potential accumulation in soils, groundwater, and plants relevant to ecology and human health. An example for the inclusion of monitoring requirements for micro-contaminants in water reuse can be found in California's Recycled Water Policy. Recent recommendations of the Science Advisory Panel for constituents of emerging concern [86] resulted in an amendment to the Water Quality Control Policy for Recycled Water [87] with regard to the monitoring of CECs combining a priority list and the use of bioanalytical assays. As the knowledge regarding microcontaminants as well as the analytical tools are dynamically developing, legislation for water reuse should enable regular review and adaptation to new findings.

\section{Conclusions and recommendations}

The chemical quality of reclaimed water is a key issue in safe agricultural irrigation. Using water containing organic micro-contaminants poses a risk to soil, groundwater, and human health. One major objective should be to prevent chemicals to accumulate in food chains and to enter groundwater potentially used for drinking purposes. This should be addressed carefully in the guidance accompanying regulations on water reuse for agricultural irrigation. In case of the proposed EU regulation, further guidance for a science-based risk assessment and the deriving of the necessary requirements and measures is needed. Guidance should include sufficient details to promote widely harmonized risk management approaches and systematic monitoring. The monitoring of suitable indicator substances and quality control should be established for reclaimed water, e.g., using effect-based methods as well as for the environmental matrices (soil, groundwater) at the irrigated sites.

Any evaluation of micro-contaminant removal during soil passage should cover a series of aspects, from the quality of the reclaimed water to the end uses of the groundwater, as well as the compound's intrinsic properties and the particular properties of the soil. To minimize the contamination of the soil and the groundwater at the source, water used for agricultural irrigation should comply with stringent quality requirements, including chemical parameters pertaining to organic micro-contaminants. Urban wastewaters containing influents from hospitals or indirect discharges from certain industrial processes that use hazardous chemicals (such as electroplating, other surface finishing, painting, or textile processing) are not suitable for water reuse without additional targeted treatment. Wastewater reuse can also be problematic in areas where appropriate and well-maintained urban wastewater treatment is not feasible. This is more likely to be the case in low-income and middle-income countries. Wastewater treatment techniques should be adapted to remove organic microcontaminants from wastewater, in particular PBT and PMT chemicals. The selection of adequate wastewater treatment techniques should take into account the specific microbial and chemical composition of the wastewater. In addition, a combination of active measures at the source, good agricultural practices, and additional preventive measures (e.g., knowledge transfer and/or the education of the stakeholders involved) are necessary to bring about and ensure safe water reuse for irrigation.

Finally, in light of increasing conflicts among different uses of water (drinking water, ecosystem needs, irrigation, transport of effluents, cooling) and a changing climate, it is important to more generally consider water demand management. Often, potentials remain to better adapt the crop selection and farming methods as well as to optimizing irrigation techniques and procedures to reduce water consumption. Water saving efforts, efficiency enhancements, and reducing water loss should be a priority in all sectors.

\section{Abbreviations}

PBT: persistent bioaccumulative toxic; PMT: persistent mobile toxic; UN:

United Nations; SDG: Sustainable Development Goals; BMZ: Bundesministerium für wirtschaftliche Zusammenarbeit und Entwicklung/Federal Ministry 
for Economic Cooperation and Development; DWA: Deutsche Vereinigung für Wasserwirtschaft, Abwasser und Abfall; PUB: Singapore's National Water Agency; JRC: Joint Research Center; EU: European Union; UK: United Kingdom; EWA: European Water Association ; CEC: contaminants of emerging concern; WHO: World Health Organization; ISO: International Organization for Standardization; SCHEER: Scientific Committee on Health, Environmental and Emerging Risks; UNESCO: United Nations Educational, Scientific and Cultural Organization; FAO: Food and Agriculture Organization of the United Nations; EEA: European Environment Agency; NLWKN: Niedersächsischer Landesbetrieb für Wasserwirtschaft, Küsten- und Naturschutz; E. coli: Escherichia coli; HACCP: Hazard Analysis and Critical Control Point; UV: ultraviolet.

\section{Acknowledgements}

\section{Not applicable.}

\section{Authors' contributions}

$\mathrm{MH}$ has been responsible for the concept of the manuscript, drafted the manuscript and was a major contributor to the manuscript. EF and CS helped further elaborating the manuscript and contributed specific aspects. All authors read and approved the final manuscript.

\section{Funding}

Not applicable.

\section{Availability of data and materials}

Not applicable presented information is based on previously published data only.

\section{Ethics approval and consent to participate}

Not applicable.

\section{Consent for publication}

Not applicable.

\section{Competing interests}

The authors declare that they have no competing interests.

\section{Author details}

1 Umweltbundesamt, Wörlitzer Platz 1, 06844 Dessau-Roßlau, Germany.

2 Bundesanstalt für Geowissenschaften und Rohstoffe (BGR), Stilleweg 2, 30655 Hannover, Germany.

Received: 15 October 2019 Accepted: 29 December 2019

Published online: 18 January 2020

\section{References}

1. Geis M (2018) Wir sind die Gewinner. In: Die Zeit 51/2018 (in German)

2. United Nations (2015) Transforming our world: the 2030 Agenda for Sustainable Development. Resolution adopted by the General Assembly on 25 September 2015. A/RES/70/1

3. Borrmann S (2013) Globaler Wandel und Konfliktpotenzial: Die Klimaänderung als Hintergrund von Verteilungskämpfen und Kriegen um Wasser. In: Hoff G (ed) "Grenzfragen"mit dem Thema „Konflikte um Ressourcen - Kriege um Wahrheit", Band Nr. 38, Salzburg (in German)

4. UNESCO (2017) The United Nations world water development report 2017: wastewater. The Untapped Resource, Paris

5. BMZ (2017) BMZ Wasserstrategie - Schlüssel zur Umsetzung der Agenda 2030 und des Klimaabkommens. Bundeministerium für wirtschaftliche Zusammenarbeit und Entwicklung. BMZ Papier 08/2017, Bonn (in German)

6. European Commission (2012) A blueprint to safeguard Europe's water resources COM/2012/0673 final

7. European Commission (2018) Proposal for a Regulation of the European Parliament and the council on minimum requirements for water reuse. 337 final 2018/0169 (COD) Brussels, 28 May 2018

8. Lazarova V (2013) Global milestones in water reuse: keys to success and trends in development. Water 21:12-22

9. DWA (2019) DWA-Topics - Non-Potable Water Reuse - Development, Technologies and International Framework for Agricultural, Urban and
Industrial Uses. In: DWA Deutsche Vereinigung für Wasserwirtschaft (eds) Abwasser und Abfall e. V, June 2019

10. Tal A (2006) Seeking Sustainability: Israel's evolving water management strategy. Science 313:1081

11. Smith D, Sedlak D, Dower R, Archuleta E, Mosher J U.S. EPA (United States Environmental Protection Agency) (2018) Mainstreaming potable water reuse in the United States: Strategies for levelling the playing field. Final Report on a Workshop organized by the U.S. Environmental Protection Agency, in partnership with the Reinventing the Nation's Urban Water Infrastructure research consortium and The Johnson Foundation at Wingspread on October 25-27, 2017

12. Tal A (2016) Rethinking the sustainability of Israel's irrigation practices in the drylands. Water Res 90:387-394

13. PUB Singapore's National Water Agency (2018) https://www.pub.gov.sg/ watersupply/fournationaltaps/newater

14. EWA (2017) E-Water. Official Publication of the European Water Association (EWA), 2007

15. WHO (2006) Guidelines for the safe use of wastewater, excreta and greywater. World Health Organization, Geneva

16. WHO (2017) Guidelines for drinking-water quality: fourth edition incorporating the first Addendum. World Health Organization, Geneva. ISBN 978-92-4-154995-0

17. ISO (2015) Guidelines for treated wastewater use for irrigation projectsPart 1-3, ISO 16075-1-3:2015. Beuth Verlag, Berlin

18. Becerra-Castro C, Lopes AR, Vaz-Moreira I, Silva EF, Manaia CM, Nunes OC (2015) Wastewater reuse in irrigation: a microbiological perspective on implications in soil fertility and human and environmental health. Environ Int 75:117-135

19. Alcalde-Sanz L, Gawlik BM (2017) Minimum quality requirements for water reuse in agricultural irrigation and aquifer recharge-towards a legal instrument on water reuse at EU level, EUR 28962 EN, Publications Office of the European Union, Luxembourg. ISBN 978-92-79-77175-0. doi: https://doi.org/10.2760/804116, PUBSY No. 109291

20. SCHEER (Scientific Committee on Health, Environmental and Emerging Risks), Scientific advice on Proposed EU minimum quality requirements for water reuse in agricultural irrigation and aquifer recharge, 9 June 2017

21. FAO (2017) A report produced for the G20 Presidency of Germany. Food and Agriculture Organization of the United Nations, Rome. ISBN 978-92-5-109977-3

22. Bahri A (1987) Meeting Tunisia's Future water needs - the role of marginal waters in Tunisia. Environmental impact of marginal waters and sewage sludge use in Tunisia, Dissertation, Department of Water Resources Engineering, Lund Institute of Technology, Lund University

23. Mahjoub O, Leclercq M, Bachelot M, Casellas C, Escande A, Balaguerc B, Bahri A, Gomez E, Fenet H (2009) Estrogen, aryl hydrocarbon and pregnane $X$ receptors activities in reclaimed water and irrigated soils in Oued Souhil area (Nabeul, Tunisia). Desalination 246:425-434

24. EEA European Environment Agency (2018) Use of freshwater resources.https://www.eea.europa.eu/data-and-maps/indicators/use-offreshwater-resources-2/assessment-3

25. Anon (2006) Regulation (EC) No 1907/2006 of the European Parliament and of the Council of 18 December 2006 concerning the Registration, Evaluation, Authorisation and Restriction of Chemicals (REACH). Off J EU 2006(L396):1-849

26. Reemtsma T, Berger U, Arp HPH, Gallard H, Knepper TP, Neumann M, Quintana JB, de Voogt P (2016) Mind the gap: persistent and mobile organic compounds - water contaminants that slip through. Environ Sci Technol 50:10308-10315

27. Margot J, Rossi L, Holliger C (2015) A review of the fate of micropollutants in wastewater treatment plants. Wiley Interdisclip Rev Water 2:457-487

28. Heberer $T$ (2002) Tracking persistent pharmaceutical residues from municipal sewage to drinking water. J Hydrol 266:175-189

29. Joss A, Zabaczynski S, Göbel A, Hoffmann B, Löffler D, McArdell CS, Ternes TA, Thomsen A, Siegrist H (2006) Biological degradation of pharmaceuticals in municipal wastewater treatment: proposing a classification scheme. Water Res 40:1686-1696

30. Reemtsma T, Weiss S, Mueller J, Petrovic M, Gonzalez S, Barcelo D, Ventura F, Knepper T (2006) Polar pollutants entry into the water cycle by municipal wastewater: a European Perspective. Environ Sci Technol 40:5451-5458 
31. Verlicchi P, Al Aukidy M, Zambellom E (2012) Occurrence of pharmaceutical compounds in urban wastewater: removal, mass load and environmental risk after a secondary treatment-a review. Sci Total Environ 429:123-155

32. Loos R, Carvalho R, António DC, Comero S, Locoro G, Tavazzi S, Paracchini B, Ghiani M, Lettieri T, Blaha L, Jarosova B, Voorspoels S, Servaes K, Haglund P, Fick J, Lindberg RH, Schwesig D, Gawlik BM (2013) EU-wide monitoring survey on emerging polar organic contaminants in wastewater treatment plant effluents. Water Res 47:6475-6487

33. Luo Y, Guoa W, Ngo HH, Nghiem LD, Ibney Hai F, Zhang J, Liang S, Wang XC (2014) Review on the occurrence of micropollutants in the aquatic environment and their fate and removal during wastewater treatment. Sci Total Environ 473-474:619-641

34. Fenet H, Mathieu O, Mahjoub Li Z, Hillaire-Buys D, Casellas C, Gomez E (2012) Carbamazepine, carbamazepine epoxide and dihydroxycarbamazepine sorption to soil and occurrence in a wastewater reuse site in Tunisia. Chemosphere 88:49-54

35. Fries E, Mahjoub O, Mahjoub B, Berrehouc A, Lions J, Bahadir M (2016) Occurrence of contaminants of emerging concern (CEC) in conventional and non-conventional water resources in Tunisia. Fresh Environ Bull 25:3317-3339

36. Jemai I, Ben Aissa N, Gallali T, Chenini F (2013) Effects of municipal reclaimed wastewater irrigation on organic and inorganic composition of soil and groundwater in Souhil Wadi Area (Nabeul, Tunisia). Hydrol Curr Res 4:1-17

37. Ferrando-Climent L, Collado N, Buttiglieri G, Gros M, Rodriguez-Roda I, Rodriguez-Mozaz S, Barceló D (2012) Comprehensive study of ibuprofen and its metabolites in activated sludge batch experiments and aquatic environment. Sci Total Environ 438:404-413

38. Grossberger A, Hadar Y, Borch T, Chefetz B (2014) Biodegradability of pharmaceutical compounds in agricultural soils irrigated with treated wastewater. Environ Pollut 185:168-177

39. Williams CF, McLain JET (2012) Soil persistence and fate of carbamazepine, lincomycin, caffeine, and ibuprofen from wastewater reuse. J Environ Qual 41:1473-1480

40. NLWKN - Niedersächsischer Landesbetrieb für Wasserwirtschaft, Küstenund Naturschutz (2014) Regionaler Themenbericht, Rückstände von Arznei- und Röntgenkontrastmitteln im Grundwasser. Untersuchung in Abwasser- bzw. Klärschlammverregnungsgebieten im Raum Braunschweig-Wolfsburg. Band 20

41. NLWKN - Niedersächsischer Landesbetrieb für Wasserwirtschaft, Küstenund Naturschutz (2017) Regionaler Themenbericht, Rückstände von Arznei- und Röntgenkontrastmitteln im Grund- und Oberflächenwasser Wiederholende und ergänzende Untersuchung in Abwasser- bzw. Klärschlammverregnungsgebieten im Raum Braunschweig-Wolfsburg. Band 30

42. Siemens J, Huschek G, Siebe C, Kaupenjohann M (2008) Concentrations and mobility of human pharmaceuticals in the world's largest wastewater irrigation system, Mexico City-Mezquital Valley. Water Res 42:2124-2134

43. Breedveld GD, Roseth R, Sparrevik M, Hartnik T, Tem LJ (2003) Persistence of the de-icing additive at an abandoned airport. Water Air Soil Poll 3:91-101

44. Christou A, Agüera A, Bayona JM, Cytryn E, Fotopoulos V, Lambropoulou D, Manaia CM, Michael C, Revitt M, Schröder P, Fatta-Kassino D (2017) The potential implications of reclaimed wastewater reuse for irrigation on the agricultural environment: the knowns and unknowns of the fate of antibiotics and antibiotic resistant bacteria and resistance genes-a review. Water Res 123:448-467. https://doi.org/10.1016/j.watres.2017.07.004

45. Underwood JC, Harvey RW, Metge DW, Repert DA, Baumgartner LK, Smith RL, Roane TM, Barber LB (2011) Effects of the antimicrobial sulfamethoxazole on groundwater bacterial enrichment. Environ Sci Technol 45:3096-3101

46. Blaine AC, Rich CD, Sedlacko EM, Hyland KC, Stushnoff C, Dickenson ERV, Higgins CP (2014) Perfluoroalkyl acid uptake in lettuce (Lactuca sativa) and Strawberry (Fragaria ananassa) irrigated with reclaimed water. Environ Sci Technol 48(24):14361-14368

47. Carter LJ, Harris E, Williams M, Ryan JJ, Kookana RS, Boxall ABA (2014) Fate and uptake of pharmaceuticals in soil-plant systems. J Agric Food Chem 62(4):816-825

48. Christou A, Papadavid G, Dalias P, Fotopoulos V, Michael C, Bayona JM, Piña B, Fatta-Kassinos D (2019) Ranking of crop plants according to their potential to uptake and accumulate contaminants of emerging concern. Environ Res 170:422-432

49. Macherius A, Eggen T, Lorenz W, Moeder M, Ondruschka J, Reemtsma $T$ (2012) Metabolization of the bacteriostatic agent triclosan in edible plants and its consequences for plant uptake assessment. Environ Sci Technol 46(19):10797-10804

50. Riemenschneider C, Seiwert B, Moeder M, Schwarz D, Reemtsma T (2017) Extensive transformation of the pharmaceutical carbamazepine following uptake into intact tomato plants. Environ Sci Technol 51(11):6100-6109

51. Wu X, Dodgen LK, Conkle JL, Gan J (2015) Plant uptake of pharmaceutical and personal care products from recycled water and biosolids: a review. Sci Total Environ 536:655-666

52. Felizeter S, McLachlan MS, De Voogt P (2012) Uptake of perfluorinated alkyl acids by hydroponically grown lettuce (Lactuca sativa). Environ Sci Technol 46:11735-11743

53. Krippner J, Falk S, Brunn H, Georgii S, Schubert S, Stahl T (2015) Accumulation potentials of Perfluoroalkyl Carboxylic Acids (PFCAs) and Perfluoroalkyl Sulfonic Acids (PFSAs) in maize (Zea mays). J Agric Food Chem 63:3646-3653

54. Wen B, Li L, Zhang H, Mab Y, Shan X-Q, Zhang Z (2014) Field study on the uptake and translocation of perfluoroalkyl acids (PFAAs) by wheat (Triticum aestivum L.) grown in biosolids-amended soils. Environ Pollut 184:547-554

55. Miller EL, Nason SL, Karthikeyan KG, Pedersen JA (2016) Root uptake of pharmaceuticals and personal care product ingredients. Environ Sci Technol 50(2):525-541

56. Prosser RS, Sibley PK (2014) Human health risk assessment of pharmaceuticals and personal care products in plant tissue due to biosolids and manure amendments, and wastewater irrigation. Environ Int 75:223-233

57. Pinnekamp J (Editor) (2019) 52. ESSENERTAGUNG für Wasserwirtschaft "Wasser und Gesundheit"vom 20.-22.3.2019 in Aachen. Ges. z. Förderung d. Siedlungswasserwirtschaft an der RWTH Aachen e.V., Aachen, 2019

58. Cornel P, Mohr M, Nocker A, Selinka H-C, Schramm E, Stange C, Drewes JE (2018) Relevanz mikrobiologischer Parameter für die Wasserwiederverwendung. Fact Sheet zum WavE-Querschnittsthema „Risikomanagement in der Wasserwiederverwendung". DECHEMA e.V

59. Selinka H-C, Botzenhart K, Feuerpfeil I, Puchert W, Schmoll O, Szewzyk R, Willmitzer $H$ (2011) Detection of viruses in raw water as a basic tool for risk assessment. Bundesgesundheitsblatt 54:496-504 (in German)

60. UBA_Umweltbundesamt (2014): Empfehlung des Umweltbundesamtes nach Anhörung der Trinkwasserkommission „Vorgehen zur quantitativen Risikobewertung mikrobiologischer Befunde im Rohwasser sowie Konsequenzen für den Schutz des Einzugsgebietes und für die Wasseraufbereit ung"Bundesgesundheitsblatt 57,1224-1230

61. Exner M, Schmithausen R, Schreiber C, Bierbaum G, Parcina M, Engelhart S, Kistemann T, Sib E, Walger P, Schwartz T (2018) Zum Vorkommen und zur vorläufigen hygienisch-medizinischen Bewertung von Antibiotikaresistenten Bakterien mit humanmedizinischer Bedeutung in Gewässern, Abwässern, Badegewässern sowie zu möglichen Konsequenzen für die Trinkwasserversorgung. Hyg Med 43(5):D46-D54

62. Krzeminski P, Tomei MC, Karaolia P, Langenhoff A, Almeida CMR, Felis E, Gritten F, Andersen HR, Fernandes T, Manaia CM, Rizzo L, Fatta-Kassinos D (2019) Performance of secondary wastewater treatment methods for the removal of contaminants of emerging concern implicated in crop uptake and antibiotic resistance spread: a review. Sci Total Environ 648:1052-1081

63. Rizzo L, Manaia C, Merlin C, Schwartz T, Dagot C, Ploy MC, Michael I, Fatta-Kassinos D (2013) Urban wastewater treatment plants as hotspots for antibiotic resistant bacteria and genes spread into the environment: $a$ review. Sci Total Environ 447:345-360

64. Carey DE, McNamara PJ (2014) The impact of triclosan on the spread of antibiotic resistance in the environment. Front Microbiol 5(780):1-11

65. Piña B, Bayona JM, Christou A, Fatta-Kassinos D, Guillon E, Lambropoulou D, Michael C, Polesel F, Sayen S (2018) On the contribution of reclaimed wastewater irrigation to the potential exposure of humans to antibiotics, antibiotic resistant bacteria and antibiotic resistance genes-NEREUS COST Action ES1403 position paper. J Environ Chem Eng. https://doi. org/10.1016/j.jece.2018.01.011

66. Natural Resource Management Ministerial Council, Environment Protection and Heritage Council, Australian Health Ministers Conference (2006) 
National guidelines for water recycling: managing health and environmental risks. ISBN 1921173076

67. Natural Resource Management Ministerial Council, Environment Protection and Heritage Council, Australian Health Ministers Conference (2008) Australian guidelines for water recycling: augmentation of drinking water supplies. ISBN 1921173203

68. WHO (2009) Water safety plan manual: step-by-step risk management for drinking-water suppliers. World Health Organization, Geneva

69. WHO (2015) Sanitation safety planning: manual for safe use and disposal of wastewater, greywater and excreta. World Health Organization, Geneva

70. Rebelo A (2019) New Portuguese Law-Decree on water reuse, presentation at ISO/TC 282. Water Reuse International Workshop, Lisbon | LNEC | https://committee.iso.org/files/live/sites/tc282/files/Resources/New_PT_ LD_ISO_WS_22_05_2019.pdf. Accessed 22 May 2019

71. UBA_Umweltbundesamt (2017) Scientific opinion paper, Recommendations for deriving EU minimum quality requirements for water reuse. 1 June 2017

72. Jekel M, Dott W (2013) Leitfaden: Polare organische Spurenstoffe als Indikatoren im anthropogen beeinflussten Wasserkreislauf. Ergebnisse des Querschnittsthemas „Indikatorsubstanzen“. DECHEMA e.V. http://riskw a.de/RiSKWa//RISKWA_Leitfaden_Indikatorsubstanzen final.pdf

73. Ternes T et al. (2004) POSEIDON Assessment of Technologies for the Removal of pharmaceuticals and Personal Care Products in Sewage and Drinking Water Facilities to Improve the Indirect Potable Water Reuse. POSEIDON Final Report. http://undine.bafg.de/servlet/is/2888/Final -Report-POSEIDON

74. Ternes TA, Bonerz M, Herrmann N, Teiser B, Andersen HR (2007) Irrigation of treated wastewater in Braunschweig, Germany: an option to remove pharmaceuticals and musk fragrances. Chemosphere 66(5):894-904

75. González O, Bayarri B, Aceña J, Pérez S, Barceló D (2016) Treatment technologies for wastewater reuse: fate of contaminants of emerging concern. In: Fatta-Kassinos D, Dionysiou D, Kümmerer K (eds) Advanced treatment technologies for urban wastewater reuse. The handbook of environmental chemistry, vol 45. Springer, Cham, pp 5-37

76. Mulligan CN, Yong RN (2004) Natural attenuation of contaminated soils. Environ Int 30(4):587-601

77. Banzhaf S, Nödler K, Licha T, Krein A, Scheytt T (2012) Redox-sensitivity and mobility of selected pharmaceutical compounds in a low flow column experiment. Science Total Environ 438:113-121

78. Brack W, Aissa SA, Backhaus T, Dulio V, Escher BI, Faust M, Hilscherova K, Hollender J, Hollert H, Müller C, Munthe J, Posthuma L, Seiler T-B, Slobodnik J, Teodorovic I, Tindall AJ, de Aragão Umbuzeiro G, Zhang X, Altenburger R (2019) Effect-based methods are key. The European Collaborative Project SOLUTIONS recommends integrating effect-based methods for diagnosis and monitoring of water quality. Environ Sci Eur 31:10

79. Bradley PM, Barber LB, Kolpin DW, McMahon PB, Chapelle FH (2007) Biotransformation of caffeine, cotinene, and nicotine in stream sediments: implications for use as wastewater indicators. Environ Toxicol Chem 26:1116-1121

80. Khan SJ (2010) Quantitative chemical exposure assessment for water recycling schemes. In: Water Reuse Foundation Australia Conference: Water Reuse and Desalination: Water Scarcity Solutions for the 21st Century, Sydney, NSW, Australia, presented at Water Reuse Foundation Australia Conference: Water Reuse and Desalination: Water Scarcity Solutions for the 21st Century, Sydney, NSW, Australia, 15-17 November 2010

81. Stuart ME, Lapworth DJ, Thomas J, Edwards L (2014) Fingerprinting groundwater pollution in catchments with contrasting contaminant sources using microorganic compounds. Sci Total Environ 468-469:564-577

82. Buerge IJ, Poiger T, Müller MD, Buser H-R (2003) Caffeine, an anthropogenic marker for wastewater contamination of surface waters. Environ Sci Technol 37:691-700

83. Harwood JJ (2014) Molecular markers for identifying municipal, domestic and agricultural sources of organic matter in natural waters. Chemosphere 95:3-8

84. Doummar J, Geyer T, Baierl M, Nödler K, Licha T, Sauter M (2014) Carbamazepine breakthrough as indicator for specific vulnerability of karst springs: application on the Jeita spring, Lebanon. Appl Geochem 47:150-156

85. Young TA, Heidler J, Matos-Pérez CR, Sapkota A, Toler T, Gibson KE (2008) $\mathrm{Ab}$ initio and in situ comparison of caffeine, triclosan, and triclocarban as indicators of sewage-derived microbes in surface waters. Environ Sci Technol 42:3335-3340

86. SCCWRP (2018) Monitoring Strategies for Constituents of Emerging Concern (CECS) in Recycled Water, Recommendations of a Science Advisory Panel. Jörg E. Drewes, Paul Anderson, Nancy Denslow, Walter Jakubowski, Adam Olivieri, Daniel Schlenk, Shane Snyder. Science Advisory Panel Convened by the State Water Resources Control Board. April 2018, SCCWRP Technical Report 1032

87. California Water Boards (2019) Water quality control policy for recycled water. Adopted December 11, 2018. Effective April 8, 2019, State Water Resources Control Board California Environmental Protection Agency

88. BIO by Deloitte (2015) Optimising water reuse in the EU-Final report prepared for the European Commission (DG ENV), Part I. In collaboration with ICF and Cranfield University

89. European Commission (2007) Addressing the challenge of water scarcity and droughts in the European Union COM (2007) 414, Brussels, 18.7.2007

90. Kümmerer K, Dionysiou DD, Olsson O, Fatta-Kassinos D (2018) A path to clean water. Science 361(6399):222-224

\section{Publisher's Note}

Springer Nature remains neutral with regard to jurisdictional claims in published maps and institutional affiliations.

\section{Submit your manuscript to a SpringerOpen ${ }^{\circ}$ journal and benefit from:}

- Convenient online submission

- Rigorous peer review

- Open access: articles freely available online

- High visibility within the field

- Retaining the copyright to your article

Submit your next manuscript at $\boldsymbol{\nabla}$ springeropen.com 